\title{
Short stay hospital treatment and rapid rehabilitation of cases of myocardial infarction in a district hospital
}

\author{
G. R. Royston \\ From Barnet General Hospital, Barnet, Herts.
}

Two hundred consecutive male cases of myocardial infarction have been treated along lines designed to provide a minimal time spent in bed, and in hospital, with early return to work. The method of treatment and the results are described.

Rapid rehabilitation enabled 40 per cent to be discharged within a fortnight and 87 per cent within a month. Twenty-three per cent returned to work within 4 weeks of the onset of their illness, 56 per cent within 6 weeks, and 77 per cent within 8 weeks. There were no ill effects either in hospital or during a 6-month follow-up after discharge.

Rapid rehabilitation is both possible and desirable. The active participation of a medical social worker in all cases is essential.

To many medical and most non-medical minds a myocardial infarction is still regarded as a disaster and the beginning of the end. To the patient and his relatives it carries a mental shock, often greater and more far reaching than the systemic effects of the infarction itself. A vast international body of published material has accumulated on the subject, particularly since the advent of the coronary care units. The emphasis has been on the organization and results of coronary units, drugs, particularly in relation to arrhythmia, shock, and anticoagulation. Comparatively little attention has been paid to the mental attitude of the patient and his relatives and to the time spent in bed, in hospital, and away from work.

It has been traditional to enforce a fixed period of bed rest irrespective of the severity of the case, usually 6 weeks followed by a protracted convalescence, frequently by a change of job, and sometimes by premature retirement.

Advice to change to a lighter occupation often leads to unemployment, sometimes permanent, and is damaging to morale even in a robust personality.

During the past three years a regimen of treatment has been adopted, aimed at reducing the time spent in bed and returning the patient home and back to work as soon as

Received 3 August I97I. possible. Particular attention has been paid to the psychological aspect, and to increased physical activities in hospital and at home. The medical social worker and the physiotherapist have played an active and important role in this programme. The material, method, and results for this scheme of treatment will be described.

\section{Subjects and methods}

Starting in October 1967 the first 200 consecutive male cases, of all ages, of myocardial infarction satisfying at least two of the following three criteria have been studied: (I) Characteristic clinical presentation; (2) $Q$ waves, ST elevation, or $T$ wave inversion with evolutionary changes; (3) raised serum hydroxybutyrate dehydrogenase (SHBD) > IOO IU.

The catchment area contains approximately 250,000 people and is largely dormitory with some light industry and extensive shopping areas.

All cases have been followed up for at least 6 months after discharge from hospital and the survivors interviewed by the author.

Details of death are complete, having been obtained from hospital records, general practitioners, coroners' reports, and other official sources.

All cases were admitted to the four-bedded coronary care unit at Barnet General Hospital. The unit is part of, and partially screened from, the remaining 22 beds in an acute medical ward. The ward nursing staff looked after the unit. All patients considered were admitted under one consultant (the author). 
Routine treatment consisted of oxygen, sedation, and anticoagulants ( $84 \%$ of cases). Complications are treated in the usual manner.

The following regimen is routine but suitably extended or modified if progress is unsatisfactory at any stage. Bed rest in the unit for 72 hours with bedside display of pulse rate and electrocardio-

- gram. Provided further monitoring is not indicated, the patient then moves into the main part of the ward under the supervision of the same nursing and medical staff. While in bed, he is allowed full freedom, washing, shaving, and feeding himself and using a bedside commode. Mobilization started on the fourth day with 2 hours up, followed by 8 hours on the fifth day,

- while meals are taken at a table. The day room is available for television, etc. For the next 3 days he receives progressive chair exercises in the ward as described by Currer (1967), followed by 3 days more strenuous exercises in the gymnasium. All exercises are under the supervision of a physiotherapist. Discharge home is on the eleventh day or if a week-end intervenes and the

- gymnasium is shut the fourteenth.

Before discharge the patient and his wife are interviewed by me, and the nature of his illness, his capabilities, and his future fully and frankly discussed, with the emphasis on a rapid return to a full physically active life. It is gratifying how much this personal talk is appreciated. He is also interviewed by the medical social worker and a

4 full social history taken.

Throughout his stay in hospital he is constantly encouraged and reassured by all the staff from the earliest possible moment compatible with his ability to comprehend. During this period he has

a the advantage of seeing and talking to patients who have progressed further and this provides considerable psychological benefit and is a point

t in favour of combining the unit with the general ward in which he remains and not separating them geographically.

After discharge, he attends the gymnasium for two weeks. Transport is not provided and he is encouraged to walk at least part of the way and to bring his wife to one of the later attendances so as to encourage her.

He then attends outpatients with his wife. At this final visit a written report is available from

- the physiotherapist. His wife is interviewed separately by the medical social worker who telephones her impressions to me. The patient is then examined and finally both the patient and his wife are interviewed together. Questions are invited and further reassurance given. A decision

- for returning to work or further treatment is made and a National Health certificate to that effect

- given where appropriate. A follow-up appointment is given for six months' time and anticoagulants continued where applicable.

\section{Results}

2 Age groups In a total of 200 cases, there were 152 between the ages of 40 and 65 years (Fig. I).

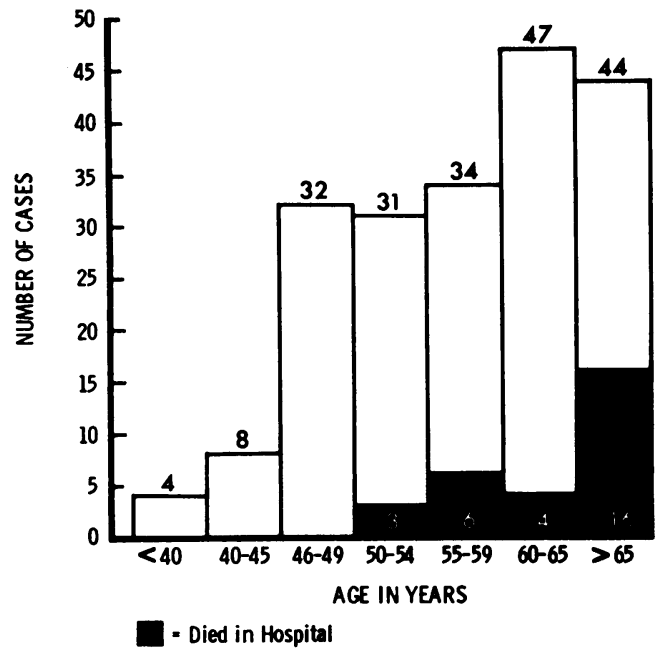

FIG. I Age of patients, and deaths in hospital.

Severity The present series has been divided into 3 simple categories estimated within 48 hours of admission. Mild, those appearing clinically fit and in whom there was no arrhythmia (a few extrasystoles excluded), no congestive cardiac failure, persistent hypotension, recurrent severe pain, or history of previous infarction. Severe, those whose condition gave rise to great anxiety and in whom survival appeared doubtful. Moderate, those between mild and severe. Using these criteria there were 105 mild cases (52.5\%), 87 moderate cases $(43.5 \%)$, and 8 severe cases $(4 \%)$.

Mortality Twenty-nine patients died in hospital (15\%). Nine had been graded as mild, I9 as moderate, and $I$ as severe, giving mortalities of 8.6 and 22 per cent for the first two grades.

Out of the 75 cases up to the age of 55, 3 died ( $4 \%$ mortality), and for those over 55 , 26 out of 125 died (21\%) (Fig. I).

Of the 29 cases who died while still in hospital, 22 were still confined to bed. Ten necropsies were performed and all confirmed myocardial infarction. Seven died after being allowed up and the 2 necropsies performed confirmed a second fresh infarction.

Fig. 2 shows the time spent in bed for those who died in hospital either before or after getting up. There is no evidence that a short stay in bed favours collapse on mobilization. Table I gives details of those who died after mobilization. 




FIG. 2 Time spent in bed for those who died before and those who died after getting up.

Cardiac rupture No cardiac rupture was found in any of the 17 necropsies performed in!hospital and within six months of discharge.
TABLE I Deaths in hospital after getting up

\begin{tabular}{|c|c|c|c|c|c|}
\hline \multirow{2}{*}{$\begin{array}{l}\text { Age } \\
(y r)\end{array}$} & \multicolumn{2}{|c|}{ No. of days } & \multirow[t]{2}{*}{ Mode of death } & \multirow[t]{2}{*}{ Necropsy } & \multirow[t]{2}{*}{ Remarks } \\
\hline & In bed & $U_{p}$ & & & \\
\hline 57 & 6 & $\mathbf{I}$ & NR & No & Heart block; old CVA \\
\hline 72 & $7 \mathrm{wk}$ & 14 & Ventric. fibrill. & No & $\begin{array}{l}\text { Chronic left ventricular } \\
\text { failure; heart block }\end{array}$ \\
\hline 73 & 9 & $\mathbf{I}$ & Sudden & $\begin{array}{l}\text { Fresh } \\
\text { infarct }\end{array}$ & $\begin{array}{l}\text { Sitting out for } \frac{1}{2} \text { hour } \\
\text { only }\end{array}$ \\
\hline 68 & 4 & $3^{\star}$ & Died in sleep & No & $\begin{array}{l}\text { Peripheral vascular } \\
\text { disease; hypertension }\end{array}$ \\
\hline 70 & 4 & 10 & $\begin{array}{l}\text { Acute left ventricular } \\
\text { failure }\end{array}$ & No & Diabetes mellitus \\
\hline $6 I$ & 6 & 3 & Ventric. fibrill. & $\begin{array}{l}\text { Original } \\
\text { infarct }\end{array}$ & Previous infarct \\
\hline 59 & 8 & 3 & Ventric. fibrill. & No & Died in bed suddenly \\
\hline
\end{tabular}

^ Sitting out only.

NR $=$ Not Recorded.

\section{Mortality after discharge from hospital}

In the I7I survivors, I2 deaths occurred within 6 months of discharge from hospital $(7 \%)$, 2 of these had returned to light work. Table 2 shows some of the details of these cases.

Table 3 shows the mortality for all cases in terms of severity according to the present classification and that of Peel et al. (1962).

TABLE 2 Deaths within six months of discharge from hospital

\begin{tabular}{|c|c|c|c|c|c|c|c|c|}
\hline \multirow{2}{*}{$\begin{array}{l}A g e \\
(y r)\end{array}$} & \multicolumn{2}{|c|}{ No. of days } & \multirow{2}{*}{$\begin{array}{l}\text { Died No. of } \\
\text { weeks after } \\
\text { discharge }\end{array}$} & \multirow{2}{*}{$\begin{array}{l}\text { Social } \\
\text { grade }\end{array}$} & \multirow[t]{2}{*}{ Necropsy } & \multirow{2}{*}{$\begin{array}{l}\text { Cause of } \\
\text { death }\end{array}$} & \multirow[t]{2}{*}{ Work } & \multirow[t]{2}{*}{ Remarks } \\
\hline & Bed & Hospital & & & & & & \\
\hline $5 I^{\star}$ & 3 & Io & 17 & I & + & $\begin{array}{l}\text { Cerebral } \\
\text { haemorrhage }\end{array}$ & Clerical & $\begin{array}{l}\text { Hypertension under } \\
\text { treatment }\end{array}$ \\
\hline $62^{\star}$ & 7 & 17 & 8 & 2 & - & Sudden & Electrician & On holiday \\
\hline $6 r$ & 3 & 14 & 4 & 2 & - & $\begin{array}{l}\text { Left ventricu- } \\
\text { lar failure }\end{array}$ & $\begin{array}{l}\text { Printing } \\
\text { machine } \\
\text { manager }\end{array}$ & $\begin{array}{l}\text { 3rd infarct.; CCF; chronic } \\
\text { left ventricular failure }\end{array}$ \\
\hline 65 & 3 & 16 & 3 & 3 & - & $\begin{array}{c}\text { Recurrent } \\
\text { infarct }\end{array}$ & Clerical & $\begin{array}{l}\text { Moderate aortic valve } \\
\text { disease }\end{array}$ \\
\hline 70 & 7 & 22 & 14 & 2 & - & Sudden & $\begin{array}{l}\text { Railway } \\
\text { worker }\end{array}$ & $\begin{array}{l}\text { Very light work past } 4 \mathrm{yr} \text {; } \\
\text { disobliterative aortic } \\
\text { endarterectomy; bilateral } \\
\text { lumbar sympathectomy }\end{array}$ \\
\hline 64 & 3 & 22 & 4 & $\mathbf{I}$ & + & $\begin{array}{l}\text { Original } \\
\text { infarct }\end{array}$ & Clerical & $\begin{array}{l}\text { Running for bus against } \\
\text { instructions }\end{array}$ \\
\hline 66 & 5 & II & $3 \mathrm{dy}$ & $\mathbf{I}$ & + & $\begin{array}{l}\text { Original } \\
\text { infarct }\end{array}$ & Clerical & \\
\hline 64 & 15 & 26 & 2 & 2 & + & $\begin{array}{c}\text { Original } \\
\text { infarct }\end{array}$ & $\begin{array}{l}\text { Water } \\
\text { bailiff }\end{array}$ & $\begin{array}{l}\text { Told to take things very } \\
\text { easily }\end{array}$ \\
\hline 59 & 7 & 20 & 4 & 3 & - & NR & Shopkeeper & Tension ++ on holiday \\
\hline 70 & 3 & 14 & 18 & $\mathbf{I}$ & - & Sudden & $\begin{array}{l}\text { Managing } \\
\text { director }\end{array}$ & $\begin{array}{l}\text { Completed world tour; part- } \\
\text { time office work only }\end{array}$ \\
\hline 68 & 3 & 15 & 20 & 3 & + & $\begin{array}{l}\text { Haemorrhage } \\
\text { car. stomach }\end{array}$ & Clerical & $\begin{array}{l}\text { Peripheral arterial disease; } \\
\text { died after emergency } \\
\text { surgery }\end{array}$ \\
\hline 65 & 7 & 17 & 5 & 2 & - & Sudden & $\begin{array}{l}\text { School } \\
\text { teacher }\end{array}$ & $\begin{array}{l}\text { Recurrent infarct; cardiac } \\
\text { arrest; due to retire in } \\
\text { few weeks }\end{array}$ \\
\hline
\end{tabular}

\footnotetext{
$\star$ Died after return to work.
} 
TABLE 3 Mortality in hospital and for six months after discharge in terms of severity of attack

\begin{tabular}{|c|c|c|c|c|c|c|c|c|c|c|c|c|c|c|c|}
\hline & & & & \multirow{2}{*}{\multicolumn{6}{|c|}{$\frac{\text { In hospital }}{\text { Moderate }}$}} & \multirow{2}{*}{\multicolumn{6}{|c|}{ Severe }} \\
\hline \multicolumn{4}{|l|}{ Mild } & & & & & & & & & & & & \\
\hline $\begin{array}{l}\text { Peel index I-9 } \\
\text { No. Died } \%\end{array}$ & $\begin{array}{l}\text { Self } \\
\text { No. }\end{array}$ & Died & $\%$ & $\begin{array}{l}\text { Peel } \\
\text { No. }\end{array}$ & $\begin{array}{l}\text { index } \\
\text { Died }\end{array}$ & $\begin{array}{l}9-16 \\
\%\end{array}$ & $\begin{array}{l}\text { Self } \\
\text { No. }\end{array}$ & Died & $\%$ & $\begin{array}{l}\text { Peel } \\
\text { No. }\end{array}$ & $\begin{array}{l}\text { index } \\
\text { Died }\end{array}$ & $\begin{array}{l}\geqslant 17 \\
\%\end{array}$ & $\begin{array}{l}\text { Self } \\
\text { No. }\end{array}$ & Died & $\%$ \\
\hline 1069 & 105 & 9 & $8 \cdot 6$ & 75 & 13 & 17.5 & 87 & 19 & 22 & 19 & 7 & 37 & 8 & $\mathbf{I}$ & 12.5 \\
\hline Out of hospital & & & & & & & & & & & & & & & \\
\hline $96 \quad 4$ & 95 & 7 & $7 \cdot 3$ & $6 I$ & 6 & 10 & 68 & 4 & 6 & 12 & 2 & I7 & 6 & $\mathbf{I}$ & 17 \\
\hline $\begin{array}{l}\text { Total for six month } \\
10613\end{array}$ & $\begin{array}{l}\text { hs } \\
\text { I05 }\end{array}$ & 16 & 15.2 & 75 & 19 & 25 & 87 & 23 & $26 \cdot 4$ & 19 & 9 & 47 & 8 & 2 & 25 \\
\hline
\end{tabular}

Bed rest of the I7I survivors, 6I (36\%) spent up to 3 days in bed. One hundred and b fifty-five $(91 \%)$ were up within ro days (Fig. 3).

Of the 43,23 were in the $60-65$ age group and spent only up to 5 days in bed.

Time spent in hospital Of the I7I survivors, $14(8 \%)$ were discharged at ro days and $54(3 \mathrm{I} \%)$ between II and I4 days, 68 $(40 \%)$ being discharged within two weeks (Fig. 4).

Return to work Type of work Of the I7I patients discharged from hospital, there were 12 deaths within 6 months before return to = work, and 23 were not working at the time of admission to hospital. Full details are known for 127 of the 136 remaining cases: 3 were unfit for further work; I05 $(82 \%)$ returned to their original work, 2 of whom died ( 6 part

FIG. 3 Time in bed for patient discharged for hospital.

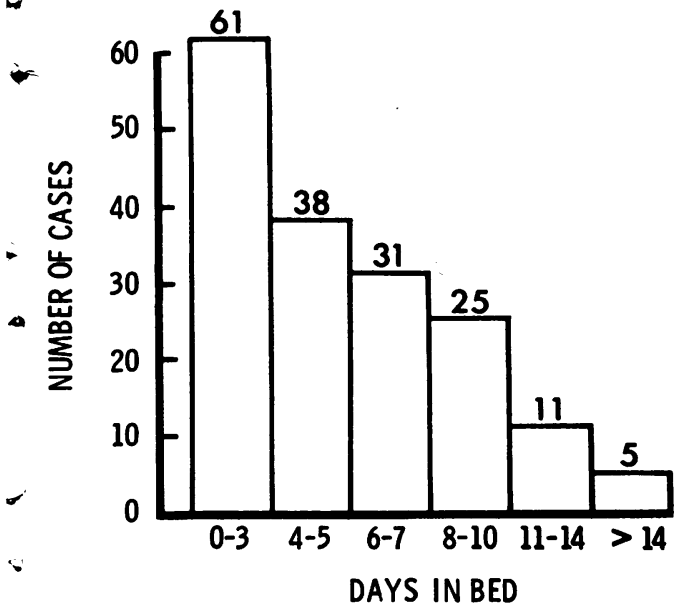

time only); 15 to their original work modified to be less arduous (2 part time only), and 4 to different work (I part time only), the remaining II are known to have returned to work but details of their work are not known.

Time off work This is known for 135 cases and was carefully checked at the 6 months' follow-up visit and is taken from the day of admission to hospital to the day of return to work; 31 (23\%) were back within one month from the onset of their attack; $78(56 \%)$ within 6 weeks; $107(77 \%)$ within 2 months and I18 (85\%) within Io weeks, and $122(90 \%)$ within 3 months (Fig. 5).

Degree of physical work The degree of physical work before admission was assessed in 4 grades: light, moderate, heavy, and very heavy. The grade was determined by the patient's description of the actual physical work done. Particulars are available for 128 survivors, Grades I, 2, 3, and 4 with 36,36 , 19, and 9 per cent, respectively.

Table 4 shows the time off work in terms of type of work. There is very little difference between the grades. It is noteworthy that the II in the very heavy group were all back at work within 8 weeks.

Delay in returning to work In 33 patients $(25 \%)$, though recovered cardiologically, there was a delay in returning to work. Influenza and respiratory tract infections accounted for II patients. Nine considered themselves unfit and 5 took a holiday. In 4 instances the family doctor considered them unfit and in a further 4 the employer was responsible. Approximately Io per cent appeared to have their return to work delayed unduly for reasons of their own. Nevertheless such delays usually only amounted to 2 to 3 weeks.

Smoking Smoking habits were known for I56 cases and were graded as follows: heavy, 


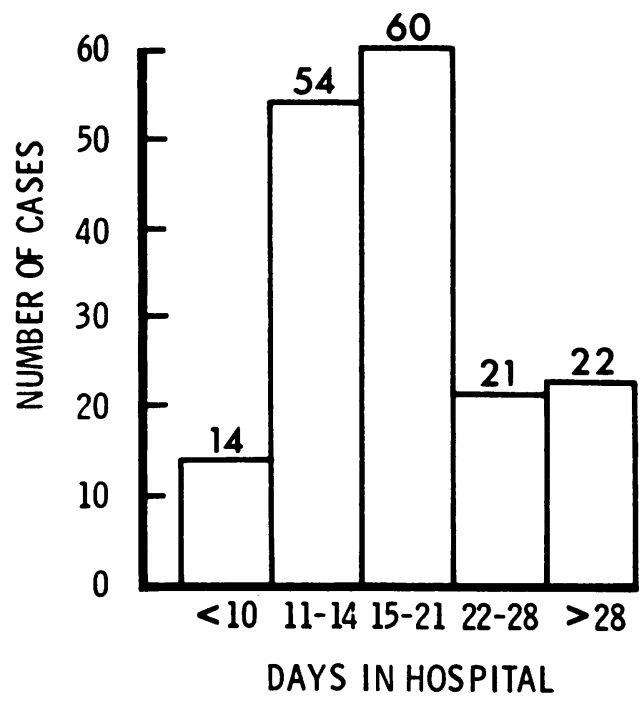

FIG. 4 Time in hospital for patients discharged from hospital.

moderate, light, nil. The severity of the infarct did not appear to be affected by the smoking habits (Table 5).

Social group The social group (General Register Office, 1960) was known for 179 cases (Table 6). There was no correlation between the severity of the infarction and the social group.

\section{FIG. 5 Return to work.}

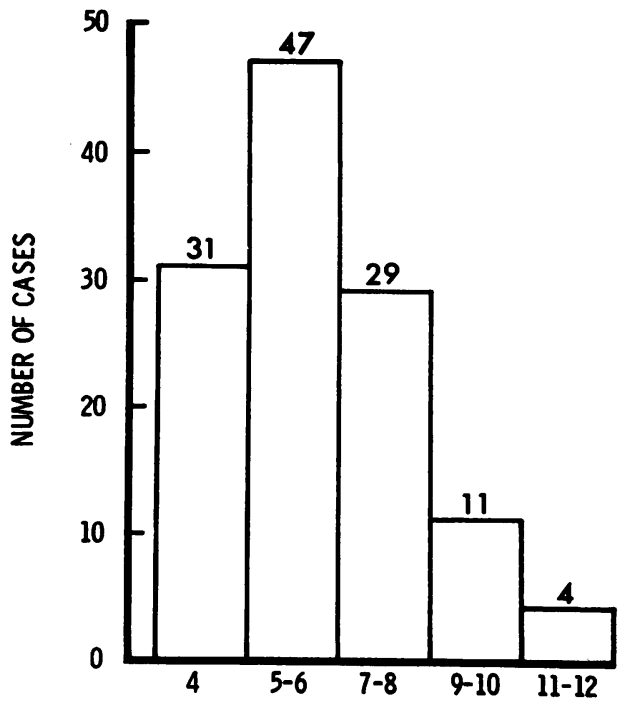

WEEKS OFF WORK FROM DAY OF ADMISSION
TABLE 4 Time off work in terms of degree of physical work

\begin{tabular}{|c|c|c|c|c|c|c|c|c|}
\hline \multirow{3}{*}{ Weeks off work } & \multicolumn{8}{|c|}{ Grade of work } \\
\hline & \multicolumn{2}{|l|}{$I$} & \multicolumn{2}{|l|}{$I I$} & \multicolumn{2}{|l|}{$I I I$} & \multicolumn{2}{|l|}{$I V$} \\
\hline & No. & $\%$ & No. & $\%$ & No. & $\%$ & No. & $\%$ \\
\hline 4 & II & 23 & 12 & 24 & 5 & 22 & 2 & 18 \\
\hline $5-6$ & 18 & 39 & 15 & 33 & 6 & 22 & 6 & 55 \\
\hline $7-8$ & 12 & 25 & I0 & 22 & 4 & 21 & 3 & 27 \\
\hline$\geqslant 9$ & 6 & 13 & IO & 21 & 8 & 35 & 0 & 0 \\
\hline Total & 47 & 100 & 47 & 100 & 23 & 100 & II & 100 \\
\hline
\end{tabular}

\section{Discussion}

Goble, Adey, and Bullen (1963) have described excellently the psychological aspects of myocardial infarction and stress the importance of including the patient's wife in discussion wherever possible; however, in addition it is important to start explanation, encouragement, and reassurance as soon after admission as the patient is capable of 'taking in' what he is told. This reassurance requires constant repetition almost amounting to 'brain-washing' and should ideally start before admission to hospital at the scene of the initial collapse and be continued by the ambulance personnel and thereafter by all grades of nursing, medical, and ancillary staff. The assumption should be 'this man has forgotten what he has been told!' A few chosen words in the early stages aimed at relieving anxiety that he will go back to his original work, just as before, often work like a charm. The sedative and analgesic effect is valuable and unlike other drugs it does not cause hypotension or vomiting; indeed it may even reduce catecholamine production.

He should be warned that much of his treatment at this early stage, such as continuous oxygen, is routine and does not mean that he is seriously ill. A similar explanation should be given to his wife before she reaches

TABLE 5 Severity of infarct and smoking habit

\begin{tabular}{|c|c|c|c|c|c|c|}
\hline \multirow[b]{3}{*}{$\begin{array}{l}\text { Smoking } \\
\text { habit }\end{array}$} & \multicolumn{6}{|c|}{ Severity of infarct } \\
\hline & \multicolumn{2}{|l|}{$I$} & \multicolumn{2}{|l|}{$I I$} & \multicolumn{2}{|l|}{$I I I$} \\
\hline & $\begin{array}{l}\text { No. of } \\
\text { cases }\end{array}$ & $\%$ & $\begin{array}{l}\text { No. of } \\
\text { cases }\end{array}$ & $\%$ & $\begin{array}{l}\text { No. of } \\
\text { cases }\end{array}$ & $\%$ \\
\hline Heavy & 20 & 61 & 13 & 39 & 0 & 0 \\
\hline Moderate & 42 & 62 & 24 & 35 & 2 & 3 \\
\hline Light & 12 & 52 & I0 & 43 & I & 5 \\
\hline Nil & 17 & 54 & 13 & 42 & 2 & 4 \\
\hline
\end{tabular}


her husband's bedside and thus minimize the spread of anxiety from one to another.

Enthusiasm for the treatment must be shown by all members of the team thereby instilling confidence in the patient.

Return to work is one of the most important - outcomes of medical care and is often delayed through lack of precise knowledge of the nature of the work involved and through lack of communication between the patient, the hospital, the family doctor, and the patient's

- family and employer. The present scheme of management largely overcomes these difficul- ties.

The age distribution for the 200 cases is similar to that of the Medical Research Council trial (1964), except that in this series there is no age limit and the M.R.C. trial limited cases s to age 65 for the first 17 months and 69 thereafter. The series does not include an undue proportion of young people compared with other series.

An attempt has been made to compare the composition of the present series with other series from the point of view of severity of attack and mortality (Table 7). A comparison has also been made (Table 8 ) between the present method of grading and that of Peel. The criteria for severe attacks were more stringent than required by Peel and account for the differences in the moderate and severe groups.

Mortality depends on many variable factors such as the incidence of bad prognostic factors and the referral habits of local practi* tioners, with particular reference to the time interval between the onset of the attack and arrival at hospital. These many variables make comparison of different series unreliable.

In the present series, the proportion of mild cases $(52.5 \%)$ is higher than in other series (Table 7) and so is the mortality after dis- charge $(7.0 \%)$, and yet the overall mortality in hospital of 15 per cent is well within the accepted range for a coronary care unit

\section{TABLE 6 Severity of infarct and social} grades

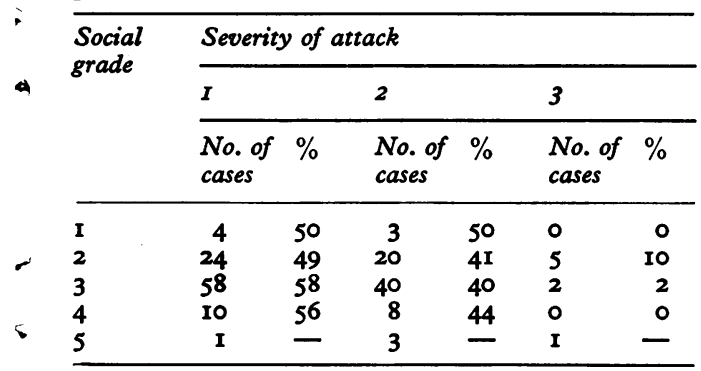

TABLE 7 Severity and mortality in coronary care units

\begin{tabular}{|c|c|c|c|c|c|c|}
\hline \multirow[b]{2}{*}{ Series } & \multirow[b]{2}{*}{$\begin{array}{l}\text { No. of } \\
\text { cases }\end{array}$} & \multicolumn{2}{|c|}{ Per cent } & \multicolumn{3}{|c|}{$\%$ Mortality } \\
\hline & & Mild & $\begin{array}{l}\text { Mod. to } \\
\text { severe }\end{array}$ & Mild & $\begin{array}{l}\text { Mod. to } \\
\text { severe }\end{array}$ & Total \\
\hline Restieaux et al. & $\star_{150}$ & & & & & I4 \\
\hline Sloman et al. & 300 & 48 & 52 & & & 27 \\
\hline Lown et al.* & 130 & & & & & 17 \\
\hline Lawrie et al.† & 400 & 30 & 70 & 4 & 24 & 17 \\
\hline Goble et al. $\neq$ & I50 & 45 & 55 & 3 & 53 & $3 I$ \\
\hline Norris et al. & 300 & 36 & 64 & 7 & 23 & 17 \\
\hline Royston & 200 & $52 \cdot 5$ & $47 \cdot 5$ & $8 \cdot 6$ & $2 I$ & 15 \\
\hline
\end{tabular}

* Includes some women.

† Included 36 cases of shock.

₹ Included 13 cases of shock.

(Thomas, Jewitt, and Shillingford, 1968). This suggests that the present method of grading tends to overestimate the mild cases and underestimate the remainder.

For those who died in hospital after getting up ( 7 out of 29), there is no evidence (Table $\mathrm{I}$ ) that early mobilization affected the outcome.

The mortality after discharge from hospital, 7 per cent for 6 months, is higher than reported in a previous series (4 per cent: Royston, 1968). However only one patient (aged 5I) was below the age of 60 , and he had a cerebral haemorrhage.

Findings at necropsy and relevant details are described in Table 2.

Bed rest There is a great lack of precise information in the published reports on the time patients spend in bed, in hospital, and before returning to work.

It is important to establish the diagnosis and, for this reason, and also to detect early arrhythmias and particularly cardiac arrest, the patient should be monitored. This means, in practice, bed rest. The brief period of 72 hours is of considerable psychological advantage as well as tending to diminish chest

\begin{tabular}{|c|c|c|c|c|}
\hline \multirow[t]{2}{*}{ Severity } & \multicolumn{2}{|c|}{ Peel index } & \multicolumn{2}{|l|}{ Self } \\
\hline & $\begin{array}{l}\text { No. of } \\
\text { cases }\end{array}$ & $\%$ & $\begin{array}{l}\text { No. of } \\
\text { cases }\end{array}$ & $\%$ \\
\hline $\begin{array}{l}\text { Mild } \\
\text { Moderate } \\
\text { Severe }\end{array}$ & $\begin{array}{r}106 \\
75 \\
19\end{array}$ & $\begin{array}{l}53 \\
37 \\
\text { 10 }\end{array}$ & $\begin{array}{r}105 \\
87 \\
8\end{array}$ & $\begin{array}{c}52 \cdot 5 \\
43 \cdot 5 \\
4\end{array}$ \\
\hline Total & 200 & 100 & 200 & 100 \\
\hline
\end{tabular}


infections and thrombophlebitis in the older age groups.

The time spent in hospital is of economic and psychological value and facilitates early return to work. Groden (1967) discharges his patients in from 3 to 5 weeks and they take a further 4 to 6 weeks to regain normal activity, and Lawrie et al. (1967) keep their patients 4 to 5 weeks in hospital. In the present series (Fig. 4) 40 per cent were discharged within a fortnight and 87 per cent within a month.

Return to work The rapidity with which a patient returns to work depends not only on himself and his medical condition but to a large extent on outside factors, often difficult to control, such as a family doctor who tends to overprotect his patient (Goble et al., 1963), a reluctant employer, or a firm where the firm's doctor has to give the all-clear in addition to the family doctor involved. Occasionally the need is to find lighter work or even a complete change of work, as Goble et al. (1963) said 'standard medical management is often inadequate to cope with the threatening situations presented to a patient who has had a coronary occlusion, thus permitting the development of disability through mounting fear or anxiety'. This problem has been almost entirely solved by the active participation of the medical social worker as a member of the team, whose participation in all cases is essential. There is a danger that applying this method of treatment, with the emphasis on early return to work, without medical social worker support, might lead to misunderstanding and even resentment on the part of the patient and his family.

Reference to Fig. 5 and Table 9 shows that in the present series almost a quarter were back at one month and the figure of 56 per cent for 6 weeks compares with other series at 12 weeks (Sharland, 1964: 55\%; Wincott and Caird, 1966: 58\% ; Groden, 1967: $44 \%$; A. W. Lawson, 1968, personal communication: $30 \%$ ).

Lawson's low figures are explained by his patients being steel workers. In a small series of patients reported from the continent of Europe (Luccioni, 1968), artisans and business people returned on the average after six months and manual workers after eight months, compared with approximately 80 per cent for artisans, 65 per cent for manual workers at 2 months for this series.

Undue delay in returning to work was restricted to a small number of cases. It is doubtful whether the considerable effort required to restrict this still further would be worth while in view of the short extra time
TABLE 9 Return to work

\begin{tabular}{lllllllll}
\hline Series & \multicolumn{3}{l}{$\begin{array}{l}\% \text { of cases } \\
\text { No. of weeks before return }\end{array}$} \\
\cline { 2 - 8 } & No. of cases & 4 & 6 & 8 & I0 & I2 & 24 \\
\hline Royston & 135 & 23 & 56 & 77 & 85 & 90 & 96 \\
Sharland & 212 & & & & & 55 & 82 \\
Wincott and Caird & 65 & & & & & 58 & 83 \\
Groden & $6 \mathrm{I}$ & & & & & 44 & 82 \\
Lawson & 43 & & & & & 30 & 83 \\
\hline
\end{tabular}

away from work involved, and the fact that all patients fit for work eventually returned.

\section{References}

Currer, N. A. (1967). Give Your Heart a Chance. Rigby, Adelaide, South Australia.

General Register Office (1960). Classification of Occupations. H.M.S.O., London.

Goble, A. J., Adey, G. M., and Bullen, J. F. (1963). Rehabilitation of the cardiac patient. Medical fournal of Australia, 2, 975.

Groden, B. M. (1967). Return to work after myocardial infarction. Scottish Medical fournal, 12, 297.

Lawrie, D. M., Greenwood, T. W., Goddard, M., Harvey, A. C., Donald, K. W., Julian, D. G., and Oliver, M. F. (1967). A coronary-care unit in the routine management of acute myocardial infarction. Lancet, 2, 109.

Lown, B., Fakhro, A. M., and Hood, W. B., Jr. (I967). The coronary care unit. New perspectives and directions. Fournal of the American Medical Association, 199, 188.

Luccioni, R. (1968). Rehabilitation professionelle des malades atteints d'infarctus du myocarde. Archives Méditerranéennes de Médecine, 45, 257.

M.R.C. Trial (1964). Second Report of the Working Party on Anticoagulant Therapy in Coronary Thrombosis to the Medical Research Council. British Medical fournal, $2,837$.

Peel, A. A. F., Semple, T., Wang, I., Lancaster, W. M., and Dall, J. L. G. (1962). A coronary prognostic index for grading the severity of infarction. British Heart fournal, 24, 745.

Restieaux, N., Bray, C., Bullard, H., Murray, M., Robinson, J., Brigden, W., and McDonald, L. (1967). I50 patients with cardiac infarction treated in a coronary unit. Lancet, 1,1285 .

Royston, G. R. (1968). Anticoagulant treatment in coronary heart disease. British Heart fournal, 30, 817.

Sharland, D. E. (1964). Ability of men to return to work after cardiac infarction. British Medical fournal, 2, 718 .

Sloman, G., Stannard, M., and Goble, A. J. (1968). Coronary care unit: a review of 300 patients monitored since 1963. American Heart fournal, 75, I40.

Thomas, M., Jewitt, D. E., and Shillingford, J. P. (1968). Analysis of 150 patients with acute myocardial infarction admitted to an intensive care and study unit. British Medical fournal, $1,787$.

Wincott, E. A., and Caird, F. I. (1966). Return to work after myocardial infarction. British Medical fournal, 2, 1302 .

Requests for reprints to Dr. G. R. Royston, 87 Brookmans Avenue, Brookmans Park, Hatfield, Herts. 